\title{
Exploring the presence of ESBL-producing bacteria in different aquatic ecosystems in England
}

Umar Anjum¹, Ruth Reid ${ }^{1}$, Haafizah Hoosen ${ }^{1}$, Antonio Peña-Fernández ${ }^{1}$

${ }^{1}$ School of Allied Health Sciences, De Montfort University, Leicester, LE1 9BH, UK.

${ }^{2}$ Facultad de Farmacia, Universidad San Pablo CEU, Urbanización Montepríncipe, Boadilla del Monte, Madrid, Spain.

Recent evidence has shown an increasing presence and distribution of extended-spectrum betalactamases (ESBLs) in the environment, which could represent a threat to public health. However, their presence in open water systems in England remains unknown despite the significant role of water in disseminating contamination and as a reservoir for biological hazards. Therefore, three sets of 30 water samples each were collected from different open water environments in Leicestershire (UK) including Leicester city in three periods of time (summer, autumn and winter) in 2017. Water samples were collected in the same locations each season using a portable water pump connected to a foam filter module according to the 1623 method (US Environmental Protection Agency). The environments monitored were: the course of the River Soar and the Grand Union Canal (a canalised section of the River Soar) throughout the city including the River Biam; lakes highly frequented for fishing or leisure (e.g. John Merricks' Lake, Kings Lear's Lake; Bennion Pools Fishing Lake); and a marina. Water samples were concentrated using the IDEXX® Filta Max system according to manufacturer's instructions and 1623 method. The DNA was extracted from each concentrated water sample with a Fast DNA® Kit. Genotypic prevalence of ESBL-producing bacteria was investigated by means of multiplex PCR. The assay was performed to detect the ESBLs: blaтем, blashv, blaoxA and blactх-м using a CTX-M-15 producing strain of Escherichia coli as a positive control. All 90 samples assessed for ESBLs were negative. However these results should be considered inconclusive, as different factors such as dilution in the surface water could have affected them, as we have previously detected the presence of ESBLs (specifically CTX-M-15) in animal faecal samples (6 waterfowls, 3 dogs and 2 foxes) collected in different parks in Leicester city in 2016. Further studies will be needed to determine the presence and distribution of ESBLs in the open water systems in England as the World Health Organisation has highlighted ESBLs as a priority to be controlled to response to the bacterial resistance phenomenon. Information about the presence and distribution of human-pathogenic bacteria harbouring ESBL enzymes is needed to develop national intervention strategies to protect the public.

Key words: ESBLs, E. coli, CTX-M, open water systems, Leicestershire 